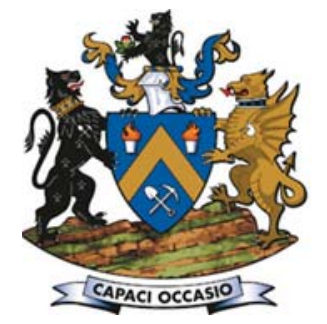

\title{
Informal settlements and mine development: Reflections from South Africa's periphery
}

\author{
by L. Marais*, J. Cloete*, and S. Denoon-Stevens ${ }^{\dagger}$
}

\section{Synopsis}

Historically, mining companies worldwide provided housing and developed towns to accommodate their employees. At the end of the 1980s this approach became less prevalent and attempts were made to mitigate the effects of mine development and mine closure on communities living near the mines. Permanent settlement in mining towns urgently needed to be minimized. Since the advent of democracy, South African policy has moved in the opposite direction, shifting the emphasis to creating integrated communities and encouraging home ownership. Despite this policy shift, however, mines continue to influence local housing conditions. One direct outcome has been the development of informal settlements. We surveyed 260 informal settlement households in Postmasburg, a small and remotely located town in the Northern Cape Province of South Africa. We found that because they employ contract workers and thus arouse expectations of employment, the mines here contribute extensively to the development of informal settlements. But local factors also contribute, and the functional role of informal settlements as a form of housing that supports mobility should not be underestimated. We also found that both municipal and mining company policies for informal settlements were inadequate. Finally, we found that low-income informal settlers not associated with mine employment suffered the highest levels of social disruption.

Keywords

mining, mining towns, informal settlements, housing policy.

\section{Introduction}

A mine generates demand for labour, which in turn generates demand for housing. When settlements spring up near a mine this often means poor housing conditions. In South Africa in the 1960s and 1970s mining companies invested heavily in company towns or mining settlements, but they have become increasingly hesitant to do so, for three reasons. First, declining resource prices in the mid-1980s and the 1990s compelled them to focus on core business interests and reduce the costs of peripheral activities such as housing (Bryceson and MacKinnon, 2013); second, at the turn of the 20th century they were often accused of taking over the role of local government (IIED, 2002) and consequently became hesitant to invest in developing mining towns; and third, changing labour regimes also curbed their investment in such towns (Haslam McKenzie, 2010). Increasingly, the companies began to endorse block-roster shifts, and outsourcing also became more common in the early 1990s. Block-roster shifts in Australia (together with improved technology) have meant that miners do not need to settle near the mines but can fly in and fly out and have their urban houses as their stable homes. This has had serious negative implications for housing in remote towns in Australia, particularly worker camps, large-scale renting out of available accommodation, and 'hot-bedding'.

In South Africa, the history of mining is closely related to apartheid planning (Mabin, 1991). Housing for black miners was constrained by influx control and institutionalized migrant labour and mostly took the form of compound living (Crush, 1994). By the mid-1980s mining companies had started to consider ownership models for their workers. By the end of the 1990s they were under pressure to upgrade their compounds to single living quarters, and living-out allowances became the norm in the industry (Crush, 1989, 1992; Rubin and Harrison, 2016). The upgrading of compounds meant that they had fewer people to accommodate and the living-out allowances made miners responsible for finding their own housing. These measures did not, however, necessarily improve the miners' living conditions and it has been argued that they contributed directly to the development of informal settlements around the mines (Marais and Venter, 2006; Rubin and Harrison, 2016). While block-roster shifts have largely failed to make inroads into the South African mining labour regime, mining has not escaped the consequences of outsourcing, which has meant

* Centre for Development Support, University of the Free State, South Africa.

+ Department of Urban and Regional Planning, University of the Free State, South Africa.

(C) The Southern African Institute of Mining and Metallurgy, 2018. ISSN 2225-6253. Paper received Sep. 2017; revised paper received Jun. 2018. 


\section{Informal settlements and mine development: Reflections from South Africa's periphery}

that large numbers of people have flocked to mining areas in the hope of being employed as contract workers. The result has been the development of large-scale informal settlements in mining towns (Cronje, 2014). As these contract workers are not directly employed by the companies, they fall outside the ambit of the companies' social responsibility and housing support programmes.

Postmasburg, in the semi-arid and sparsely populated Northern Cape Province of South Africa, was until 2010 a sleepy little town. Two events in the local mining scene were a shake-up. In 2010 Assmang, the company that owns the Beeshoek iron-ore mine about $15 \mathrm{~km}$ from Postmasburg, announced that it was relocating the people from its company town at the mine to Postmasburg itself, to make room for expansion at the mine. And then in 2011, Kumba (a company in which Anglo American has a majority share) announced that, because of the increased demand for iron ore, it was opening a new mine, Kolomela, about $23 \mathrm{~km}$ from Postmasburg. The result was an increase in Postmasburg's population from about 19000 in 1996 to the current 35000 (Statistics South Africa, 2016). In the process, large informal settlements developed in and around Postmasburg. By 2015, approximately 2500 informal housing structures had been erected, constituting about $25 \%$ of Postmasburg's housing.

Yet we do not know many details about these informal settlers, such as their place of origin, the composition of their households, their employment status, the number of household members who work on the mines, their current levels of wealth, and their place attachment to Postmasburg. The study on which this paper is based investigated these matters against the background of the international literature on mine housing and the history of mine housing in South Africa. We argue that both the local municipality and the mines (through employment, contract work, and the prospects of obtaining a job) have contributed to informal settlement development. Furthermore, the original inhabitants of the informal settlements, mostly low-income earners or unemployed, have found the influx of people a serious concern. For the many contract workers and job seekers flocking to Postmasburg, an informal housing structure represents some form of temporary accommodation that does not require a large investment and is easy to dismantle should a decision be taken to leave the town. Although informal settlement in South Africa is a muchresearched topic (Cirolia et al., 2016), far less work has been done on informal settlements in the context of mining (c.f. Rubin and Harrison, 2016, as an exception).

\section{Methods}

In 2015-2016, as part of a larger household survey in Postmasburg, we carried out a survey of 260 households in the town's informal settlements. We split the informal settlements into eight areas and conducted between 30 and 40 interviews at informal dwellings in each area, including some backyard shacks. We used a convenience sampling method to select households in the eight areas. The interviews included questions on migration, household wealth, income and expenditure, and a further range of questions on housing and social cohesion in the community. Our paper also refers to census data on the growth of informal settlements in Postmasburg.

\section{Housing problems in mining settlements: the international experience}

Up to the early 1980s mining companies globally were eager to develop company towns (Crawford, 1995). This meant that the houses belonged to the company and the miners had relatively cheap housing near the mines (Littlewood, 2014). Company towns provided good living conditions for the miners and ensured that the mines had access to labour. But the resource price slump in the mid-1980s saw the first changes being made to this policy (Marais et al., 2017). Declining commodity prices made mining companies rethink their commitment to non-core activities such as housing and the maintenance of mining towns. This trend had two consequences for the towns. In many cases their governance was transferred to democratically elected local councils, giving these councils a larger degree of local political responsibility but also burdening them with the long-term maintenance risks. In other cases the mining companies privatized the houses on their books, thus transferring the risk of homeownership to the households.

Despite the trend towards minimizing the role of mining companies in housing, the companies in many cases continued to dominate settlement development. In a global rethink of practice, the International Institute for Environment and Development (IIED, 2002) noted that, in too many cases, mining companies performed the functions of local authorities. The IIED recommended that this dominant role be reduced and a greater emphasis placed on partnerships and collaborative planning initiatives. However, the companies also wanted to guarantee a good quality of life in order to recruit skilled employees and a younger workforce.

Besides encouraging companies to investigate alternatives to mining towns, the changing labour regime has caused them to invest less in the concept of mining or company towns (Haslam McKenzie, 2010). Block-roster shifts have ensured higher salaries for miners and also substantially improved their mobility. Coupled with the introduction of fly-in fly-out arrangements in Australia, this meant that miners could fly in for three weeks of work and go home to one of the main urban areas for a week (or various permutations of this arrangement). The outcome was that formal family housing was no longer needed at mining sites. The IIED (2002, p. 221) sums up the situation thus: 'Under this system, remote mineral deposits are mined without developing traditional mining towns, and workers are brought in from outside.' The original communities are, moreover, protected from the negative implications of mining, such as a huge influx of people to the town.

Despite these changes, unintended effects of mining on settlements near mines continue to be described in the international literature. Housing and planning problems associated with mining have been recorded in North America (Halseth, 1999), Europe (Feagin, 1990), and Australia (Haslam McKenzie et al., 2009). Mining developments result in rapid population growth, and consequently pressure to release land for new houses and services (Haslam McKenzie, 2013), and also rapid increases in house prices and rental fees (Rolfe et al., 2007; Carrington, Hogg, and McIntosh, 2011; Grieve and Haslam McKenzie, 2011; Lawrie, Tonts, 


\section{Informal settlements and mine development: Reflections from South Africa's periphery}

and Plummer, 2011; Akbar, Rolfe, and Kabir, 2011; Chapman, Tonts, and Plummer, 2015). The IIED (2002, p. $65)$ says miners "still live in isolation in many parts of the world, or in overcrowded "boom towns" with few social and cultural opportunities'. The increased housing demand generated by mining raises the price of houses, making them too expensive for existing residents. Often, housing expenditure exceeds the norm of $30 \%$ of a household's total expenditure (Haslam McKenzie et al., 2009). The high prices of housing and African countries' inability to provide infrastructure have led to widespread informality around mines (Littlewood, 2014; Negi, 2014). These negative effects of an influx of people can disturb the local community's place attachment and cause social disruption (England and Albrecht, 1984).

In Australia, informality seems to have taken a somewhat different form and includes tents, temporary housing, caravans, overcrowding, 'hot-bedding', and the illegal subdivision of urban stands (Haslam McKenzie et al., 2009). The setting up of worker camps and the block booking of motels are common practices that tend to complicate longterm planning. High house prices also have negative consequences for existing mine communities, low-income families, and indigenous societies. According to Ennis, Tofa, and Finlayson (2014, p. 338), '[for] residents living in the economic shadow of major projects, the resultant housing shortages and high living costs generate economic insecurity, especially among already vulnerable populations and those on low or fixed incomes'. Obeng-Odoom $(2014$, p. 8) describes these negative consequences of mining as the 'local implications of the resource curse'.

\section{Mine housing in South Africa:}

Historically, mine housing was split along racial lines, with white miners enjoying the benefit of company towns or extensive housing allowances while black miners were mainly housed in high-density compounds and subject to institutionalized migrant labour control and influx control. Compounds originated in the diamond mining industry in Kimberley, owing to concerns about security and controlling the black miners (Crush, 1992). In this way, mobility was controlled by the state and the private sector.

By the mid-1980s the notion of home ownership for black miners had become prominent (Crush, 1989). It became possible when government lifted influx control and started granting homeownership to black middle-class residents, and when banks followed suit by offering mortgage finance. By the early 1990s, however, this new wisdom was under threat as high interest rates, mortgage boycotts, and the rapid drop in the gold price made home ownership less attractive (Tomlinson, 2007), especially in mining areas. Although various agreements between government and the private sector helped to address the situation, they did not solve the problem in areas that had to bear the consequences of mining decline (Marais, 2013). During the later 1980s and the early 1990s, many mining companies privatized their housing stock to their middle-income white employees.

With the advent of democracy in 1994, the search was on for an appropriate policy response to the years of underinvestment in housing under the apartheid government. Despite some reference to mine housing in the original White
Paper, it was only in 2002 that mine housing again rose to prominence with the Minerals and Petroleum Development Act (2002). While the Act does not refer to housing in mining areas, it requires mining companies to develop social and labour plans that are aimed at supporting local strategic plans (called integrated development plans). These social and labour plans could include housing-related matters. More specifically, government has included housing issues in the various versions of the Mining Charter (Department of Minerals and Energy, 2002; Department of Mineral Resources, 2010, 2016). By requiring that compounds be transformed into single living quarters, the various versions have rightfully got rid of the compound system. A living allowance was introduced from the mid-1990s so that miners could find their own housing, an unintended consequence of which has been the informal settlements that have developed near mining towns (Rubin and Harrison, 2016). The Mining Charter also refers to the development of integrated settlements rather than mining towns. Our review of the international literature made it clear that this approach stands in contrast to what is being done in Australia, where only limited settlement occurs near the mines. The most direct government response to housing miners in South Africa came when government introduced the Strategy for the Revitalisation of Mining Towns (Tshangana, 2015). This strategy largely focused on improving the housing conditions of miners following the Marikana massacre in 2012. This improvement has to be achieved mainly by means of the existing housing subsidy that largely (though not exclusively) provides ownership housing. To date, both municipal and mining company policies on informal settlements have been inadequate.

What started as a system controlled by both government and business has now become more flexible. The lifting of influx control, the provision of home ownership, the dismantling of the compound, and living-out allowances have shifted the onus onto the mineworkers. Mineworkers are now able make decisions and a large number have opted for housing systems that ensure mobility between places and jobs. The need to be mobile is, moreover, reinforced by the fact that mine work, especially contract work, is by definition of limited duration.

\section{Research findings}

Postmasburg offers an example of how the logic of creating integrated settlements by integrating mine and non-mine households was put into practice. The expansion of Beeshoek made both Assmang and government keen to integrate the company-town mining population with that of Postmasburg. For the company it was a way to discard activities peripheral to its core business, and the associated long-term liabilities; for government it was a way to integrate the miners with other communities. Together Assmang and Kolomela have been instrumental in constructing more than 1000 dwellings to house their staff in Postmasburg (Cloete and DenoonStevens, 2018). This has involved considerable investment by the mines. Whereas in the case of Assmang ownership was provided, Kolomela provided rental housing. The Assmang approach to home ownership is especially innovative in that a capital subsidy offered by the mine is linked to a housing allowance and an instalment-based sale 


\section{Informal settlements and mine development: Reflections from South Africa's periphery}

(as opposed to a mortgage) (Stewart and Drewes, 2018). We have mentioned the large influx of people this brought to the town, and the mushrooming of informal settlements. We have also noted that, to date, policy responses in respect of informal settlements are inadequate.

In the following sections we present our study findings about Postmasburg's informal settlers, and we compare them with the residents in formal housing.

\section{The growth of informal settlements}

According to data from Statistics South Africa (2016), Postmasburg has experienced large-scale growth in terms of the number of informal settlements. In 1996, only 750 households resided either in informal backyard dwellings or in informal houses on separate stands. By 2011, this figure had risen to nearly 2300 (current estimates are that there are now more than 3 000). While the 2011 figure indicates that $28 \%$ of the households in Postmasburg were at the time living in informal settlements, the figure for South Africa, by comparison, stood at just below 14\% (Statistics South Africa, 2016).

In Figure 1 we provide an overview of the location of the current informal settlements in Postmasburg. The most prominent space invaded by informal settlers happens to be the space between Newton and Postmasburg, this being largely due to its favourable location.

\section{Relationship with the mines}

The development of informal settlements near mining sites is often attributed to mining. Figure 2 shows the profile of informal households and their relation to mining in Postmasburg. In our survey, 75 of the 260 households (29\%) in informal houses were linked to employment by a mining company or by a contractor to the mine. Approximately $8 \%$ of these informal dwellers were employed directly by a mining company and the rest ( $21 \%$ ) by a contractor to one of the two big mines. The remaining $71 \%$ of households did not have anybody in the household employed by a mining company. But $35 \%$ settled in Postmasburg in the last ten years - most likely looking for employment. The remaining 46\% largely originated from formal Postmasburg. These figures suggest that mining has been either directly or indirectly responsible for informal settlement development. In other evidence, looking at miners only, we found that $73 \%$ of the miners in informal housing were contract workers but in formal housing the portion was only $19 \%$. These figures show that contract workers in a changing labour regime do indeed contribute to informal settlement development, as is often claimed in the media and in the academic literature.

The question then arose as to how many of the households in the informal settlements had moved to Postmasburg in search of employment, settled in informal settlements, but could not find employment. We asked nonmining households if they had been living in Postmasburg ten years earlier, and found that approximately $35 \%$ of them had moved to Postmasburg from elsewhere during the past ten years. We can thus categorize informal settler households living in Postmasburg at the time of the survey as follows:

> $46 \%$ were local households who had moved there in search of land

> $29 \%$ were employed in mine-related work ( $8 \%$ directly by the mine and $21 \%$ by subcontractors to the mine)

> The other $35 \%$ of households associated with mining were not employed by the mines at the time of the survey but, according to our data, had moved to Postmasburg in the intervening 10 years, in search of employment.

Our data shows that it is incorrect to assume that mining alone drives informal settlement development, though the pressure exerted by mining could well have been

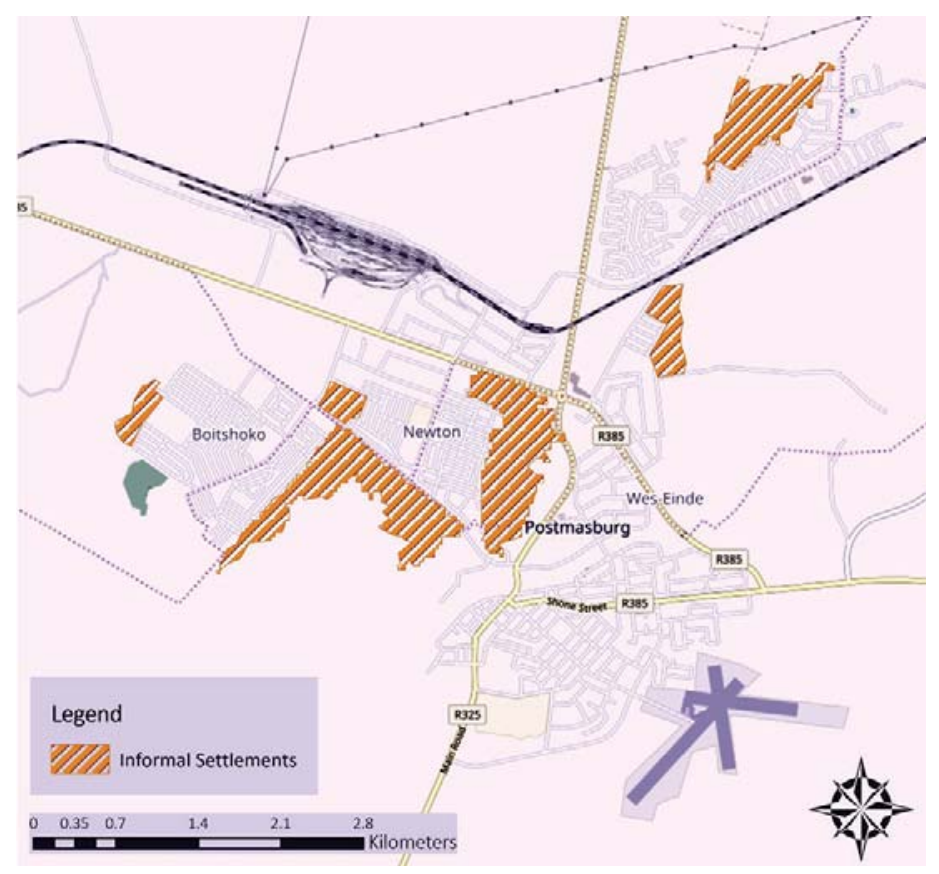

Figure 1-Location of informal settlements in Postmasburg in 2011 


\section{Informal settlements and mine development: Reflections from South Africa's periphery}

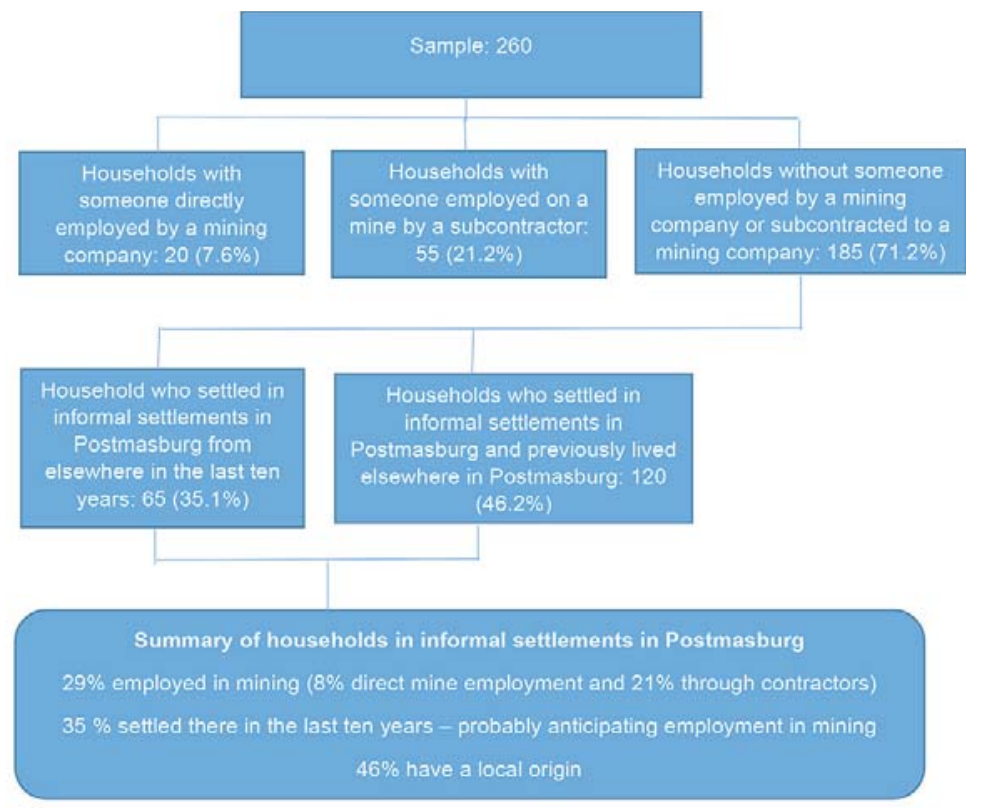

Figure 2-Overview of origin and employment of informal settlement dwellers in Postmasburg

instrumental in forming informal settlements in mining areas. Our data also shows that where mining does play a role in informal settlement formation, it is more likely to do so indirectly through contract workers or through people who have migrated to find employment than through those directly employed by the mines. Although the mines have largely provided their own employees with adequate housing, a small percentage of those directly employed by the companies still live in informal housing.

\section{Migration trends}

Given that mines historically employed migrant labour, we wanted to determine the migration trends of households living in informal houses. The overall patterns did not differ much from those of households living in formal houses, just over $28 \%$ of whom had previously lived in another town. The corresponding percentage for informal housing was $35 \%$. Consequently, some migration was ascribable to expectations of employment.

When asked whether they had lived in Postmasburg 10 years earlier, $77 \%$ of the formal and $67 \%$ of the informal dwellers said they had indeed lived in Postmasburg at that time. These figures show that a higher degree of mobility was associated with the informal settlements (a relationship that is also statistically significant): thirty-three per cent of the household members living in informal houses at the time of the survey had lived elsewhere 10 years earlier.

\section{Housing and demographic characteristics}

The household demographics show that males constituted a slight majority in informal settlement households (61.8\%). Conversely, $49.5 \%$ of members of formal households were male. Although this difference is not statistically significant, it does tend to show a predominance of male-dominated households in the informal settlements. Language differences did, however, exhibit statistically significant relationships:
Afrikaans- and Setswana-speaking households (the two dominant local languages) were less likely to be living in an informal settlement than were Sesotho- and Xhosa-speaking households. As for education levels, the households in informal settlements had substantially fewer Grade 12 or post-Grade 12 qualifications. For example, while $32 \%$ of the residents in formal houses had a Grade 12 or a post-Grade 12 certificate, this was true of only $16 \%$ of those who lived in informal houses.

We found a substantial difference between the formal and informal housing profiles. The average number of rooms in informal houses was 2.15, compared with 5.5 in formal houses. Household size was slightly smaller in the informal houses (three persons per household) in comparison with 3.3 persons in formal houses. This means that there were 0.72 rooms per household member in the informal houses compared with 1.7 rooms per person in the formal houses. The non-mining households in the informal settlements had larger houses (on average 2.32 rooms per house) than did mining households (1.85). Overall, $78 \%$ of households in the informal settlements said they owned their houses. In this regard, there was not much difference between mining and non-mining households, with approximately $78 \%$ of both groups saying they owned the informal house. The current market value of these informal houses (at the time of the survey) was just over R16 000. But households linked to mining employment (either directly employed or as contract workers) had paid substantially more for their informal houses (R9216) than those not engaged in mining (R5800). This confirms that mining salaries do indeed create some demand for informal houses. Furthermore, $13.1 \%$ of the respondents living in informal houses said that they were paying rent. It is noteworthy that the average monthly rentals of non-miner households were higher (R713) than those of miner households (R550). Mine employment and informal housing seem to provide contract workers with a means of reducing expenditure and saving on living costs. 


\section{Informal settlements and mine development: Reflections from South Africa's periphery}

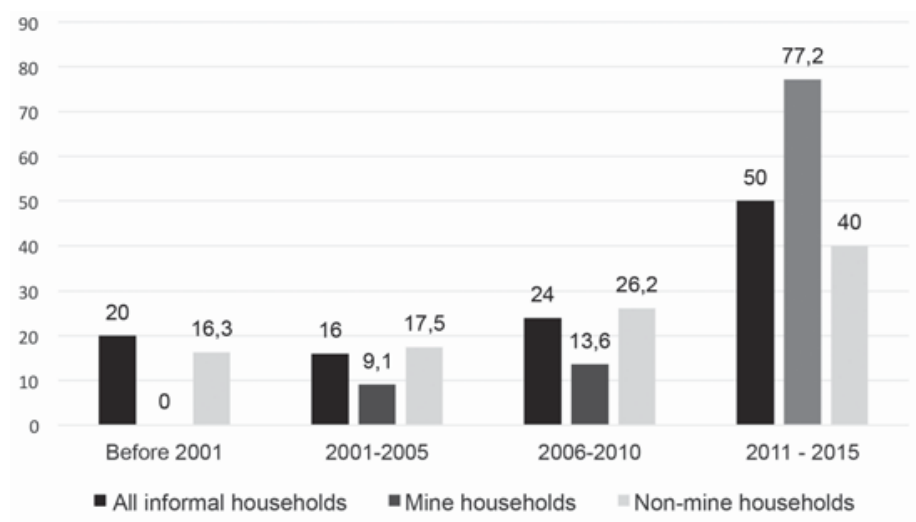

Figure 3-The percentage of households buying their informal houses in Postmasburg

As is to be expected, respondents from informal houses were much less satisfied than those in formal houses with the condition of their housing. Only 30\% claimed to be happy, and $57 \%$ said that they were unhappy (the scale made provision for 'happy', 'satisfied', and 'unhappy'). The corresponding figures for those in formal houses were $51 \%$ 'happy' and 18\% 'unhappy'. When we compared mining households with non-mining households, we found that 35\% of the households employed in mining were happy, in comparison with only $27 \%$ of the non-mining households.

Possession of second homes was less common among households living in informal houses. Only seven $(2.7 \%)$ of these respondents said they had a second home, compared with $9.5 \%$ of the households in formal houses. Three of the seven respondents living in informal houses were letting the second house and the remaining four said friends and family used the second home.

A substantial percentage of respondents in the informal settlement said they had bought their houses. Figure 3 shows that $50 \%$ of the informal houses were bought between 2011 and 2015. This coincides with the resettlement of employees from Beeshoek to Postmasburg and the construction and opening of the Kolomela mine. The fact that non-mine households constituted about $45 \%$ of households in informal settlements shows that local factors not connected with the mining industry also contributed to informal settlement development.

\section{Access to infrastructure and services}

As expected, informal households had substantially lower access to basic infrastructure than did formal households. Only $40 \%$ of informal houses had access to water on the stand and the remaining $60 \%$ had to use a public tap. However, only $9 \%$ of the respondents in informal houses said that they were paying the municipality for water - largely because the municipality has been unable to extend services to these areas. Respondents living in informal houses and who had mining employment were more likely to have to use a public tap (68\%) than those who did not have mining employment (55\%). Only 14\% of the households in informal housing had water access further than $200 \mathrm{~m}$ away - the national benchmark in this regard. Once again, this percentage was slightly higher for mine-employed respondents. An interesting finding is that the informal housing respondents were less likely to say they had had water disruptions during the previous six months. Only 50\% of the respondents living in informal houses said that they had had water disruptions, as against $70 \%$ of those living in formal houses.

Similar disparities featured in respect of sanitation. Just under $60 \%$ of the respondents in informal housing had either a bucket system or no system at all. Because recent research has shown that sharing a toilet facility has negative health implications (Marais and Cloete, 2014), we investigated the situation in Postmasburg. Having to share such a facility was slightly more common for respondents in informal (26\%) than formal housing (23\%). However, having to share a toilet facility was more common for miner households in formal $(27 \%)$ than in informal housing $(26 \%)$.

Only $31 \%$ of those living in informal houses had electricity. Power cuts because of non-payment were virtually absent in both informal and formal houses because most of them had prepaid electricity meters.

Only $10 \%$ of respondents living in informal houses said that waste removal took place, compared with $86 \%$ of respondents who lived in formal houses.

\section{Economic status}

As regards employment, there was not much difference between households in the informal and formal settlements. In the informal settlements, $41 \%$ of the adult residents were employed, compared with $43 \%$ in the formal settlements. More specific findings in respect of employment were that $73 \%$ of formal households and $63 \%$ of informal households had income from employment. Self-employment income in informal settlements $(5.8 \%)$ was also lower than in the formal settlements (7.9\%). Although households receiving an old-age grant were substantially fewer in informal houses $(7 \%)$ than in formal houses (18\%), substantially more households in informal houses reported receiving a child support grant (40\%) than was the case in formal houses (25\%). Interestingly enough, the informal households were less likely to receive donations or remittances from elsewhere $(6 \%)$ than were formal households (10\%).

There was a marked difference between formal and informal households' average monthly incomes: on average 


\section{Informal settlements and mine development: Reflections from South Africa's periphery}

\begin{tabular}{|c|c|c|c|c|c|c|}
\hline \multicolumn{7}{|c|}{$\begin{array}{l}\text { Table I } \\
\text { Distribution of assets in Postmasburg }\end{array}$} \\
\hline \multirow[t]{2}{*}{ Number of assets } & \multicolumn{2}{|c|}{ Formal housing } & \multicolumn{2}{|c|}{ Informal housing } & \multicolumn{2}{|c|}{ Informal: mine employed } \\
\hline & $n$ & $\%$ & $n$ & $\%$ & $\mathrm{n}$ & $\%$ \\
\hline $\begin{array}{l}0-3 \\
4-7 \\
9-11 \\
12-15 \\
\text { Total } \\
\text { Average }\end{array}$ & $\begin{array}{c}39 \\
177 \\
430 \\
98 \\
744 \\
8.4\end{array}$ & $\begin{array}{c}5.2 \\
23.8 \\
57.8 \\
13.2 \\
100.0 \\
3.2\end{array}$ & $\begin{array}{c}169 \\
63 \\
28 \\
2 \\
262 \\
3.3\end{array}$ & $\begin{array}{c}64.5 \\
24.0 \\
10.7 \\
0.8 \\
100.0\end{array}$ & $\begin{array}{c}63 \\
22 \\
7 \\
0 \\
92\end{array}$ & $\begin{array}{c}68.5 \\
23.9 \\
7.6 \\
0 . \\
100.0\end{array}$ \\
\hline
\end{tabular}

just over R8200 for the former but below R4000 for the latter. The difference in average monthly household expenditure was similar: R6230 for formal households and R3320 for informal households. Similar disparities were found in income and expenditure for informal households both linked and not linked to the mining industry: income of R7501 and expenditure of R5248 for the former, and income of R2730 and expenditure of R2270 for the latter.

We also assessed informal and formal households' assets (Table I). In the absence of reliable income and expenditure data in surveys such as this, access to household assets usually provides a good indication of households' economic status. Of a list of 15 household assets, households in informal settlements owned an average of 3.2 compared with 8.4 in formal settlements. The housing assets of informal mining households were marginally more (3.3), which points to miners earning better salaries, though it also shows that the circumstances of informal housing do not support the accumulation of household assets.

Having asked about household income and assets, we next asked respondents two questions about how they ranked themselves in comparison to other households. First they had to rate their own income relative to other households on a five-point Likert scale, with 1 representing 'much above average income' and 5 'much below average income'. As could be expected, the informal respondents' average ranking of their own income at 3.9 was lower than the 3.2 ranking returned by formal dwellers. Also, the rankings by respondents from mining households were higher than those of non-mining households (3.6 compared with 4.1), which supports the income and expenditure disparities we have already mentioned.

The respondents were then asked to rank themselves on a six-rung ladder, with the first rung representing the poorest and the sixth the richest, at age 15, 10 years ago, and at the time of the survey, 2015 (Table II). The 2015 rating should be interpreted against the fact that the survey followed the slump in iron ore prices in June of that year. The overall economic climate in the town was grim, and the 2015 ratings are consequently all much lower than those of 2005. The fact that contract workers are generally the first to suffer the effects of mine downscaling is the main reason why residents in the informal houses, where more contract workers live, returned lower rankings than those living in formal houses.

\section{Place attachment}

Broadly, 'place attachment' refers to a positive relationship between people and places (Hummon, 1992). To measure place attachment, we asked respondents whether they wanted to stay on at their current location; whether they thought it was likely that a lost wallet containing R200 and contact details would be returned to them by someone from the community; and how they perceived the crime situation in the area. Given the prevailing insecurity of tenure in informal settlements, place attachment in these settlements is usually much stronger than in formal settlements - mainly because of the fear of being evicted. We found that $76 \%$ of respondents in the informal settlements had a very strong preference for staying on at their current location, compared to $57 \%$ of respondents from the formal settlements. As regards the likelihood of getting the wallet back if it was picked up by someone from the community, many more respondents in the informal (34\%) than formal settlements (7\%) considered it very likely. Strangely, however, more respondents from mining (46\%) than non-mining households $(27 \%)$ considered it very likely. This might be an indication that the non-mining households perceive the mining households as intruding into 'their' space and not part of their community.

To measure differences in perceptions of crime we again used a five-point Likert scale, with 5 representing a specific crime being a very common occurrence and 1 as never happening. Table III shows that in the 'burglaries, muggings or theft' category and the 'drug or alcohol abuse' category there were virtually no differences between the perceptions of respondents in formal and informal houses. However, for the four other categories we found that the informal dwellers considered themselves exposed to higher levels of those crimes. And further, informal dwellers not involved in mining employment considered themselves exposed to higher levels of crime than did informal dwellers engaged in mine-related employment. These findings strongly suggest that the highest level of social disruption is experienced by the informal dwellers who have been living in Postmasburg for a longer time and who are not employed in mining.

Table /I

\section{Postmasburg respondents' wealth ranking}

\begin{tabular}{|l|c|c|}
\hline Time of ranking & Formal housing & Informal housing \\
\hline Aged 15 & 3.06 & 2.92 \\
Ten years ago (2005) & 2.92 & 2.54 \\
At the time of the survey (2015) & 2.76 & 2.39 \\
\hline
\end{tabular}




\section{Informal settlements and mine development: Reflections from South Africa's periphery}

\begin{tabular}{|c|c|c|c|c|}
\hline \multicolumn{5}{|c|}{$\begin{array}{l}\text { Table III } \\
\text { Postmasburg respondents' perceptions of crime (Likert-scale ratings) }\end{array}$} \\
\hline Crime & Formal housing & Informal housing & Informal non-mine households & Informal mine households \\
\hline $\begin{array}{l}\text { Burglaries, muggings, or thefts } \\
\text { Violence between members of the same household } \\
\text { Violence between members of different households } \\
\text { Gangsterism } \\
\text { Murder, shootings, or stabbings } \\
\text { Drug or alcohol abuse }\end{array}$ & $\begin{array}{l}3.61 \\
2.77 \\
2.68 \\
3.43 \\
2.86 \\
4.22\end{array}$ & $\begin{array}{l}3.68 \\
3.20 \\
3.19 \\
3.78 \\
3.32 \\
4.22\end{array}$ & $\begin{array}{l}3.87 \\
3.37 \\
3.37 \\
4.05 \\
3.52 \\
4.42\end{array}$ & $\begin{array}{l}3.44 \\
2.90 \\
2.88 \\
3.30 \\
2.98 \\
3.87\end{array}$ \\
\hline
\end{tabular}

\section{Conclusion}

Globally, mining activities exert pressure on existing settlements near mines. Since the early 1990s, mining companies have been withdrawing from the peripheral responsibilities involved in company towns and companyprovided housing. Although changing labour regimes have, in some locations, reduced the industry's dependence on mining towns, in other cases they have led to the deterioration of local housing conditions. Since the 1990s, a larger degree of outsourcing has created a situation in which mining companies are no longer responsible for housing everyone working on the mine.

This paper has outlined the poor housing conditions in Postmasburg. The mushrooming of 2300 informal houses has been closely (though not exclusively) associated with mining development. We compared the residents in the informal houses with those in formal houses. We conclude with four observations, taking into account the international literature and the policy environment.

Firstly, our evidence shows that mining is directly and indirectly responsible for the massive growth in informal houses experienced in Postmasburg. In its direct manifestation, it is apparent from the evidence in this paper that mine-employed households have been buying informal housing structures since 2011. Indirectly, then, there is also evidence that most households with mine employment (nearly two-thirds) are employed on a contract basis at the mines. Outsourcing and mine contract work have thus definitely contributed to increased informal housing development in Postmasburg. There is also more indirect evidence in that people in informal settlements have migrated to Postmasburg in the hope of finding employment. In essence, the influx of people living in informal settlements is the result of a combination of mine employment, contract work, and the expectation of finding work at one of the two mines.

Secondly, we question whether the informal settlement development associated with mine contract work is necessarily a negative phenomenon. The limited duration of contract work means that mobility is an important factor for such households, and living in an informal house provides the necessary mobility. Further evidence that these contract workers themselves do not have long-term prospects of remaining in Postmasburg is demonstrated in that miners living in the informal settlements tend to have smaller households and invest less in their houses or the associated infrastructure - despite their receiving larger salaries and spending more money than do households in informal settlements who do not have mine employment. These factors all show that living in an informal house represents an attempt to manage specific housing needs without having to invest too heavily. Postmasburg's remote location means that finding non-mining employment there is unlikely, so the mobility that informal settlement allows is an asset to job seekers.

Thirdly, mining is not the only driving force in the formation of informal settlements. More than $50 \%$ of the households in Postmasburg's informal houses are not linked to mine development. The high levels of child support grants and the low levels of old age pensions paid to informal dwellers indicate that local household formation also contributes to informal settlement development. However, it is not clear whether the growth in informal settlements associated with mine development has sparked further informal settlement development among local people. What is clearer is that informal settlement development started long before the post-2011 mining boom.

Fourthly, the question arises as to what the most appropriate policy responses from mining companies and the municipality would be. Government policy emphasises the integration of mining communities and home ownership. But since our evidence shows that these informal settlements are dependent on mining, perhaps government emphasis on ownership should be challenged? The current policy on informal settlement upgrading provides for interim service delivery even though the land has not been proclaimed. This policy acknowledges that the mobility concerns of households do not necessarily end with the provision of ownership. Perhaps the important point here is that the mines have taken pains to provide both ownership and rental housing to their employees. However, neither the mines nor the municipality have attempted (within the existing policy framework) to address the plight of informal dwellers. The mines could well justify their active involvement from a health point of view. This could mean fewer households having to share toilet facilities and more households having good access to water and electricity, which should indeed contribute to better health and enhance productivity. In the final analysis, an approach that accommodates some form of informality would be a sensible response. It is, however, up to the municipality and the mining companies to make the mind-shift. One should also acknowledge the presence of serious capacity constraints at the municipal level, such as those related to technical ability and the ability of the governance structures to deal with the mines on an equal footing. Thus, even though the presence of mining ought to be an asset to local government in remote locations, this seldom occurs in practice. 


\section{Informal settlements and mine development: Reflections from South Africa's periphery}

Finally, we found that the informal dwellers not employed by the mines have experienced the highest degrees of social disruption in Postmasburg. Increases in the numbers of informal dwellers have been viewed most negatively by the original community and by those informal dwellers not directly associated with mine employment. This supports one of the most important findings of many social disruption studies, namely that disruption of place attachment usually has the most damaging effects on the poorest households.

\section{References}

AKBAR, D., RolfE, J., and KABIR, Z. 2011. Predicting impacts of major projects on housing prices in resource based towns with a case study application to Gladstone, Australia. Resources Policy, vol. 38. pp. 481-489.

Bryceson, D. and Mackinnon, D. 2013. Eureka and beyond: mining's impact on African urbanisation. Journal of Contemporary African Studies, vol. 30, no. 4. pp. 513-517.

Carrington, K., Hogg, R., and McIntosh, A. 2011. The resource boom's underbelly: criminological impacts of mining development. Australian and New Zealand Journal of Criminology, vol. 44, no. 3. pp. 335-354.

Chapman, R., Tonts, M., and Plummer, P. 2015. Resource development, local adjustment, and regional policy: resolving the problem of rapid growth in Pilbara, Western Australia. Journal of Rural and Community Development, vol. 9, no. 1. pp. 72-86.

Cirolia, L Görgens, T., VAn Donk, M., Smit, W., and Drimie, S. 2016. Upgrading Informal Settlements in South Africa: A Partnership-based Approach. University of Cape Town Press, Cape Town.

Cloete, J. and Denoon-Stevens, S. 2018. Mineworker housing. Mining and Community in South Africa: From Small Town to Iron Town. Marais, L., Burger, P., and Van Rooyen, D. (eds.). Routledge, London. pp. 141-157.

Crawford, M. 1995. Building the Workingman's Paradise: The Design of American Company Towns. Verso, London.

CRonje, F. 2014. Digging for Development: The Mining Industry in South Africa and Its Role in Socio-economic Development. South African Institute for Race Relations, Johannesburg.

CRUSH, J. 1989. Accommodating black miners: home-ownership on the mines. South African Review 5. Ravan Press, Johannesburg. pp. 335-347.

CRUSH, J. 1992. The compound in post-apartheid South Africa. Geographical Review, vol. 82, no. 4. pp. 388-400.

CRUSH, J. 1994. Scripting the compound: power and space in the South African mining industry. Environment and Planning D: Society and Space, vol. 12, no. 3. pp. 301-324.

Department of Mineral Resources. 2010. Publication of the Amendment of the Broad-based Socio-economic Empowerment Charter for the South African Mining and Minerals Industry. Pretoria.

Department of Mineral Resources. 2016. Review of the Broad-based Black Economic-Empowerment Charter for the South African Mining and Minerals Industry. Government Printer, Pretoria.

Department of Minerals And EnERgy. 2002. Broad-based Socio-economic Empowerment Charter for South Africa's Mining Industry. Department of Minerals and Energy and Chamber of Mines, Johannesburg.

England, J. and AlBReCHT, S. 1984. Boomtowns and social disruption. Rural Sociology, vol. 49, no. 2. pp. 230-246.

EnNis, G., ToFA, M., and Finlayson, M. 2014. Open for business but at what cost? Housing issues in boomtown Darwin. Australian Geographer, vol. 45 , no. 4. pp. 447-464.

FEAGIN, J. 1990. Extractive regions in developed countries: a comparative analysis of the oil capitals, Houston and Aberdeen. Urban Affairs Quarterly, vol. 25. pp. 591-619.

Grieve, S. and Haslam McKenzie, F. 2011. Local housing strategies: responding to the affordability crisis. Planning Perspective in Western Australia: A Reader in Theory and Practice. Alexander, G. S., and Hedgcock, D. (eds.). Freemantle Press, Freemantle. pp. 66-85.

HALSETH, G. 1999. We came for the work': Situating employment migration in
B.C.'s small, resource-based communities. The Canadian Geographer, vol. 43, no. 4. pp. 363-381.

Haslam McKenzie, F. 2010. Fly-in fly-out: the challenges of transient populations in rural landscapes. Demographic Change in Australia's Rural Landscapes. Landscape Series, vol. 12. pp. 353-374.

Haslam McKenzie, F. 2013. Delivering enduring benefits from a gas development: governance and planning challenges in remote Western Australia. Australian Geographer, vol. 44, no. 3. pp. 341-358.

Haslam McKenzie, F., Phillips, R., Rowley, S., Brereton, D., and Birdsall-Jones, C. 2009. Housing market dynamics in resource boom towns. AHURI final report no. 135, Australian Housing and Urban Research Institute Limited Melbourne. http://www.ahuri.edu.au/publications/p80370/

Hummon, D. 1992. Community attachment: local sentiment and sense of place. Place Attachment. Altman, I. and Low, S. (eds.). Springer, New York. pp. 253-276.

IIED (International Institute for Environment and Development). 2002. Breaking New Ground: Mining, Minerals, and Sustainable Development. Earthscan, London.

Lawrie, M., Tonts, M., and Plummer, P. 2011. Boomtowns, resource dependence and socio-economic well-being. Australian Geographer, vol. 42 , no. 2 . pp. 139-164.

LiTTLEWood, D. 2014. 'Cursed' communities? Corporate social responsibility (CSR), company towns and the mining industry in Namibia. Journal of Business Ethics, vol. 120. pp. 39-63.

Mabin, A. 1991. The dynamics of urbanisation since 1960. Apartheid City in Transition. Swilling, M., Humphries, R., and Shubane, K. (eds.). Oxford University Press, Cape Town. pp. 33-47.

MARAIS, L. 2013. The impact of mine downscaling on the Free State Goldfields. Urban Forum, vol. 24. pp. 503-521.

Marais, L. and Cloete, J. 2014. "Dying to get a house?" The health outcomes of the South African low-income housing programme. Habitat International, vol 43, no 1. pp. 48-60.

MARAis, L. and Venter, A. 2006. Hating the compound, but ... Mineworker housing needs in post-apartheid South Africa. Africa Insight, vol. 36, no. 1. pp 53-62.

Marais, L., van Rooyen, D., Burger, P., Lenka, M., Cloete, J., Denoon-Stevens, S., MocwagaE, K., JacoBs, M., and RIET, J. 2017. The background to the Postmasburg study. Mining and Community in South Africa: From Small Town to Iron Town. Marais, L., Burger, P., and Van Rooyen, D. (eds.). Routledge, London. pp. 5-22.

NEGI, R. 2014. 'Solwezi mabanga': ambivalent developments on Zambia's new mining frontier. Journal of Southern African Studies, vol. 40, no. 5 . pp. 999-1013.

Obeng-Odoom, F. 2014. Oiling the Urban Economy: Land, Labour Capital and the State in Sekondi-Takoradi, Ghana. Routledge, London.

Rolfe, J., Miles, B., Lockie, S., and Ivanova, G. 2007. Lessons from the social and economic impacts of the mining boom in the Bowen Basin, 20042006. Australasian Journal of Regional Studies, vol. 13, no. 2. pp. 134-153.

RUBIN, M. and HARRISON, P. 2016. An uneasy symbiosis: mining and informal settlement in South Africa, with particular reference to the Platinum Belt in North West Province. Upgrading Informal Settlements in South Africa: A Partnership-based Approach. Cirolia, L., Görgens, T., van Donk, M. Smit, W., and Drimie, S. (eds.). University of Cape Town Press, Cape Town. pp. 145-173.

Statistics South Africa. 2016. Census data. Statistics South Africa, Pretoria.

StewART, T. and Drewes, E. 2018. The Khumani approach to homeownership in Postmasburg. Mining and Community in South Africa: From Small Town to Iron Town. Marais, L., Burger, P., and Van Rooyen, D. (eds). Routledge, London. pp. 141-157.

TomLinson, M. 2007. The development of a low-income housing finance sector in South Africa: Have we finally found a way forward? Habitat International, vol. 31, no. 1. pp. 77-86.

Tshangana, M. 2015. Selected Committee Presentation on the Revitalisation of Distressed Mining Towns Programme. National Department of Human Settlements, Pretoria. 